\title{
Islamic Finance and the Issue of Unauthorised Agency
}

\author{
Mohammad Mahbubi Ali* \\ Hamzah Kamaruzaman**
}

The notion of tasarruf fudhuli (disposition of unauthorised agency, hereafter referred to as 'unauthorised agency') in Islamic financial institutions (IFIs) has invoked an ongoing debate among Shari'ah scholars and Muslim economists alike. Some perceive its application in IFIs as a violation of the general axiom of wealth protection that prohibits the encroachment of another's property as an important aspect of the protection of lawfully-owned property. On the other hand, many assert that the ratification feature under the concept attracts product innovation and offers flexibility to IFIs to rectify transactions involving the issue of unauthorised agent.

Classical Muslim jurists held diametrically opposed views on the legitimacy of unauthorised agents. The Hanbali school and the renewed fatwa of the Shafi' $i$ school (qawl jadid) held that unauthorised agency is null and void. However, the Hanafis and Malikis consider it valid, its effectiveness only suspended (mawquf) contingent upon ratification by the person for whom the contract is intended. Once ratification occurs, the act becomes conclusively valid and all the legal effects that the Shari'ah has assigned to it are established.

The opponents of the concept argue that unauthorised agents constitute an encroachment of another's property. A person should have legal authority (wilayah) when entering into a contract. Ex-post approval, therefore, does not necessarily rectify the contract. The Qur'anic verse on the prohibition of consuming other's property illegally (4:39) further substantiates this position. In contrast, the advocates of this concept recognise unauthorised agents are an exception to the general Shari'ah principle with regard to dealing with another person's property. There are precedents in the Shari'ah of similar rules that stand as exceptions to general principles, considered as concessions (rukhshah) to facilitate the fulfilment of people's needs and to avoid hardship. Apart from that, the nature of the concept is essentially gratuitous, in that it is intended for the best interest of the concerned party. 'Urwah al-Bariqi has reported that the Prophet (pbuh) gave him a dinar to buy a sheep. He bought two sheep, sold one of them for a dinar, and so brought the Prophet a sheep and a dinar. The Prophet then invoked a blessing on him for his business dealing (al-Bukhari, no. 3370).

In the modern Islamic finance landscape, the view that recognises the unauthorised agent as completer a suspended contract is favourable for three 
reasons. First, the disposition of self-styled agents is a gratuitous act intended for the best interests of the owner. It does not inflict any harm on the owner since he is given liberty to either nullify or ratify the action. Second, immediate nullification of contracts creates practical complexity as institutions tend to use boilerplate contracts to undertake the same basic type of transaction with thousands of clients, with some contracts involving cross-border transactions. Third, the Hanafi and Maliki views provide more flexibility for market players to rectify the transaction.

The vast majority of contemporary Shari'ah scholars and fatwa-issuing bodies have generally adopted the view of the Hanafis and Malikis in this regard. The Shari'ah Standard No. 23 of the Accounting and Auditing Organization for Islamic Financial Institutions (AAOIFI) provides that unauthorised agency is a suspended contract and remains pending until the principal ratifies it. Upon ratification, the contract shall be effective and enforceable retrospectively. AlQuradaghi (2009) noted that some Islamic banks have applied the concept in certain circumstances. However, he stressed that the use of unauthorised agency in Islamic financial transactions has to be restricted to exceptional circumstances and treated on a case-by-case basis. It should not become a customary business practice. Each case should be individually presented to the bank's Shari'ah board for approval.

Al-Baraka Fatwa Committee was consulted on a case involving the issue of unauthorised agency. The case was a partnership between a customer and AlBaraka to co-own a vehicle. The customer agreed with the manufacturer to pay $10 \%$ of the price and Al-Baraka to pay the remaining $90 \%$. The Committee was of the view that since the customer did not obtain the bank's consent prior to dealing with the manufacturer, the bank should have the right to either ratify the arrangement or reject it. However, the Committee maintains that this principle should only be applied in a very restricted manner and should not be taken as a general principle, given that it is based on the person's intention, which is difficult to objectively determine.

The Shari'ah Advisory Council of Bank Negara Malaysia (SAC BNM) in its $139^{\text {th }}$ meeting, held 2013, raised their concern about the suitability of the concept within the Islamic banking structure. This is because unauthorised agency normally takes place randomly, unlike financial instruments that are properly structured and pre-arranged.

Accordingly, this article proposes the following for the application of unauthorised agency in the modern Islamic financial system:

1. The tasarruf fudhuli is attributed to another person, which can be evidenced by his written or verbal disclosure. 
One of the fundamental criteria for an act to qualify as unauthorised agency is that it be attributed to the concerned party. In this regard, if the person attributes the act to himself using another's property/money, he will be regarded as a usurper (ghasib). However, if the unauthorised agent purchases an asset using his own money for another person, two scenarios can be envisaged:

a. where the unauthorised agent does not disclose that the purchase is made on behalf of another, the contract is enforceable against the unauthorised agent;

b. where the unauthorised agent discloses that the purchase is made on behalf of another person, the contract is enforceable provided that the act is for the benefit/interest of the principal and postact approval is obtained. Otherwise, it is enforceable against the unauthorised agent.

2. The tasarruf fudhuli is intended to secure the interest of the owner.

Another fundamental criterion for an act to qualify as unauthorised agency is that it be dedicated to the best interests of the rightful owner. This is because unauthorised agency falls under the rubric of a gratuitous act that serves the best interest of the owner.

3. The unauthorised agent should have legal capacity to assume the role of agent.

In Islamic contract law, a person should have legal capacity to enter into a contract so that he can express a valid offer and acceptance. Jurists define legal capacity as the ability to assume rights and responsibilities and the capacity to bear the legal consequences of one's actions in accordance with Shari'ah principles. Among the important criteria for legal capacity are that a person be of the age of majority, sane, not mentally impaired, and with the ability to distinguish between what is harmful and what is beneficial to his interests. Failure to fulfil these conditions will make the contract null and void and thus without legal effect.

The condition of having legal capacity is also applicable to the unauthorised agent on the grounds that it is a valid contract pending ratification by the owner. Once ratified, the unauthorised agent is transformed into a valid and effective agent (wakalah) with all the associated legal effects. The AAOIFI in its Shar'iah standard on wakalah also stipulates that wakil shall have full legal capacity. 
4. Ratification is subject to certain conditions:

a. The owner should have the legal capacity to enter into a contract at the time the contract is concluded.

b. The owner has full liberty to grant his consent to the unauthorised agent.

c. The relevant parties, i.e. the rightful owner, unauthorised agent and third party, should be alive at the time of ratification; otherwise, the contract will be invalid. This is because ratification is regarded as newly establishing a contract that was earlier suspended.

d. The subject matter of the contract must be existent at the time of ratification because the ratification is regarded as newly establishing the contract.

e. The ratification is made within a reasonable time.

5. The concept should not be accepted as a common practice or general rule. Its use should be restricted to exceptional circumstances and be treated on a random and case by case basis.

When all these conditions are duly fulfilled, it would most likely mean that unauthorised agency can be used for facilitation only of lawful benefit in financial transactions (tijarah) in the IFIs.

\section{Notes}

* Mohammad Mahbubi Ali is Research Fellow, International Institute of Advanced Islamic Studies (IAIS) Malaysia.

** Hamzah Kamaruzaman is Manager, Shari'ah Section Islamic Banking and Takaful Department, Bank Negara Malaysia. 